Animal Production in Developing Countries

Occasional Publication No. 16 - British Society of Animal Production 1993

edited by M. Gill, E. Owen, G. E. Pollott and T. L. J. Lawrence

\title{
Interspecies differences in tannin activity of leaves from 13 species of Nepalese browse trees
}

\author{
C. D. Wood ', B. N. Tiwari'², V. E. Plumb', C. J. Powell', B. T. Roberts ${ }^{1}$ and M. Gill' \\ 'Natural Resources Institute, Chatham Maritime, Kent ME4 4TB \\ ${ }^{2}$ Lumle Agricultural Centre, clo British Embassy, Kathmandu, Nepal
}

\section{Introduction}

In Nepal tree leaves are an important foodstuff for ruminants, particularly in the dry season when foods are scarce. Many tree species are used as browses in Nepal, however little is known about the antinutritive factors which they may contain. Tannins occur in many plants including some trees. Tannins interact strongly with protein hence their original use in leather making. They have also been implicated as anti-nutritional factors although their effects on animals are not fully understood. This paper describes a preliminary screening aimed at quantifying the tannin levels in some species used.

\section{Material and methods}

The fodder trees sampled were located at various altitudes in the mid hills of western Nepal. The tree species and altitudes are given in Table 1.

Duplicate leaf samples from a single specimen of each tree were taken monthly from November to March, dried at $60^{\circ} \mathrm{C}$ and sent to the National Resources Institute for analysis. Tannin activity was assayed by a modified version of a radial diffusion

Table 1 Fodder tree species analysed

\begin{tabular}{lcc}
\hline Species & Species code & Altitude \\
\cline { 1 - 3 } Ficus glaberrima & Fg & 1100 \\
Artocarpus lakoocha & Al & 1100 \\
Dendrocalanus strictus & Ds & 1100 \\
Litsea polyantha & Lp & 1100 \\
Ficus semicordata & Fs & 1650 \\
Brassaiopsis hainla & Bh & 1650 \\
Ficus roxburghii & Fr & 1650 \\
Ficus nerrifolia & Fn & 1050 \\
Quercus semicarpifolia & Qs & 2200 \\
Qutrcus lamelosa & Q1 & 2100 \\
Prunus cerasoides & Pc & 1650 \\
Castanopsis indica & Ci & 1650 \\
Castanopsis tribuloides & Ct & 1650 \\
\hline \hline
\end{tabular}

technique developed by Hagerman (1987). This assay measures the ability of tannin extracts to precipitate protein. Tannins where extracted in $70 \%$ aqueous acetone and plated on agarose plates containing $0.1 \%$ haemoglobin. Precipitation activity was calculated as the ratio of the areas of rings of test extracts divided by the area of the ring developed by a resorcinol standard expressed on a per gram of dry leaf basis.

\section{Results}

The precipitation activity of leaf extracts is shown in Figure 1. Very clear species to species differences can be observed in activity levels. For example Qs extracts were consistently very active at precipitating protein while Ds extracts did not have any activity in any of the five monthly samples. Fluctuation from month to month could be very marked for some species, slight for others. The trends shown by $\mathrm{Fg}, \mathrm{Al}$, Lp, Fs, Fr and Fn were similar in that early falls in precipitation activity were subsequently reversed.

\section{Discussion and conclusions}

Tannin content and composition is known to change as tree leaves develop (Makkar, Dawra and Singh, 1991). Seasonal differences have also been observed

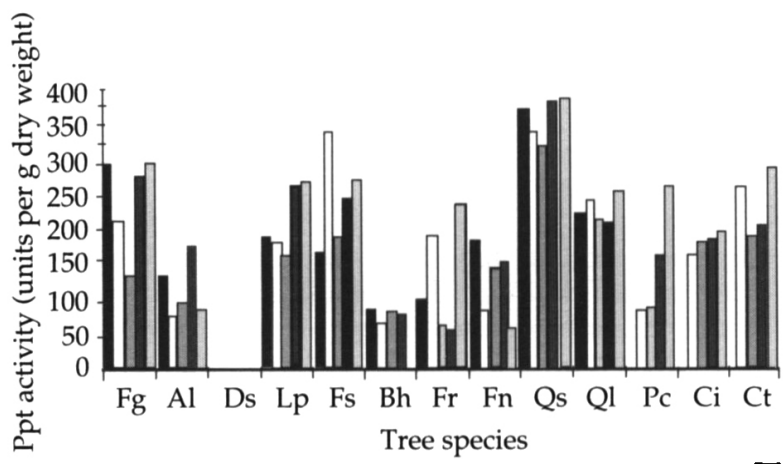

Figure 1 Tannin activity of Nepalese fodder leaf extracts. Nov. $\square$ Dec. $Q$ Jan. Feb. $\square$ Mar. For abbreviations see Table 1. 
which may or may not be linked with leaf development (Vaithiyanathan and Singh, 1989). As tannin activities have been observed to rise and fall in some species the changes are unlikely to be due only to leaf development. These fluctuations presumably occur in response to a varying environmental stimulus such as weather conditions. The importance of factors such as sunlight, water and temperature have yet to be established. A consequence of these fluctuations is that it is not possible to assume values for tannin levels: they should be measured for particular foods for feeding trials and for particular fodder species over the range of environmental conditions where they are to be used. The radial diffusion method is a relatively simple and potentially useful measure of tannin activity for screening work of this type. It does, however, need to be correlated with animal responses.

\section{Acknowledgements}

This work was funded by the Overseas Development Administration (ODA).

Lumle Agricultural Centre is funded by the ODA of the British Government and works in cooperation with Her Majesty's Government of Nepal.

\section{References}

Hagerman, A. E. 1987. Radial diffusion method for determining tannins in plant extracts. Journal of Chemical Ecology 13: 437-449.

Makkar, H. P. S., Dawra, R. K. and Singh, B. 1991. Tannin levels in leaves of some oak species at different stages of maturity. Journal of the Science of Food and Agriculture 54: 513-519.

Vaithiyanathan, S. and Singh, B. 1989. Seasonal changes in tannin contents in some top seeds in arid regions. Indian Journal of Animal Science 59: 1565-1567. 